\title{
Effect of Groundwater Quality on Yield Index and Nutrient Concentration in Stem Plant Tissue of Winter Wheat (Triticum turgidum L.)
}

\author{
Hemn Othman Salih* \\ Department of Plant Production, Khabat Technical Institute, Erbil Polytechnic University, Erbil, Kurdistan Region, Iraq
}

\author{
${ }^{*}$ Corresponding author: \\ Hemn Othman Salih, \\ Department of Plant Production, \\ Khabat Technical Institue, \\ Erbil Polytechnic University, \\ Erbil, Kurdistan Region, Iraq. \\ E-mail: hemn.salih@epu.edu.iq
}

Received: 20 December 2018

Accepted: 31 January 2019

Published: 30 October 2019

\section{DOI}

10.25156/ptj.v9n2y2019.pp11-15

\section{A B S T R A C T}

The field experiment was conducted at private land in Grdarasha southern Erbil, Iraq, to study the effect of seven water qualities having electrical conductivity of $0.42,0.50,1.43,2.20,2.60$, 5.40 , and $5.70 \mathrm{dS} / \mathrm{m}$ on chemical characteristics and growth of plant and protein percent in wheat grains in winter season of 2015-2016. The crop was cultivated on December 11, 2015, and continued growing to May 30, 2016. The experiment land was equally divided into three plots spaced $75 \mathrm{~cm}$ between them. The results showed that weights and lengths of straw and spike were reduced by W.q5 67.49 and $100.01 \mathrm{~g}$ and 51.87 and $6.30 \mathrm{~cm}$ increased with W.q3 treatment 96.58 and $139.17 \mathrm{~g}$ and 91.08 and $10.57 \mathrm{~cm}$, respectively, and wheat grains protein percentage was also increased by W.q6 (13.70) treatment comparing with minimum percentage of protein by W.q5 (7.26). The data of irrigation by saline water of W.q7 resulted concentration increasing of $\mathrm{Ca}^{2+}, \mathrm{Mg}^{2+}$, and $\mathrm{Na}^{+}(7.39,2.22$, and $4.52 \mathrm{mg} / \mathrm{g})$; while the concentrations of the same elements were $1.54,0.61$, and $1.81 \mathrm{mg} / \mathrm{g}$ by W.q2 watering, respectively. Potassium concentration was the highest $(0.16 \mathrm{mg} / \mathrm{g})$ by W.q2 water compared to minimum level $(0.06 \mathrm{mg} / \mathrm{g})$ with $\mathrm{W} . \mathrm{q} 5$ irrigation. The watering by W.q5 $(0.29 \mathrm{mg} / \mathrm{g})$ resulted was lower concentration of phosphorus in the plant compared to minimal saline water W.q3 and W.q4 $(0.34 \mathrm{mg} / \mathrm{g})$.

Keywords: Groundwater; Saline water; Wheat; Yield index

\section{INTRODUCTION}

The use of saline water for irrigation has been commonplace for 50 years, as it is obtainable in many developing countries. In the last water requirements with available resources data of the Iraqi Ministry of Water Resources in 2002 showed that the water resource predictions for 2015 would be 43.93 billion $\mathrm{m}^{3}$, and the actual need for multiple purposes will be 65.35 billion $\mathrm{m}^{3}$, which indicates the necessity of exploitation of groundwater, and the initial studies were done actually in the fifties on the quality of groundwater in the Altun Kopre basin (Persons and Ralph, 1955). On the other hand, numerous studies were conducted in Kurdistan region by Esmail, 1992; Dohuki, 1997; Esmail et al., 2007; Salih, 2008; Dohuki et al., 2013; Rajab, 2015; Alani, 2015; and Salih, 2018.

Most of the water resources suffer from inconsistencies in their quantity and paucity in quality due to the environmental changes associated with the continuous industrial and agricultural expansion. However, the large expansion of the use intermediate level of saline water in both irrigation and studies in the field has been reported; the field management of using this water for agricultural purposes still requires further researches to diminish soil salinity risk that costs extremely human life. Most plants tolerate to a certain level of salinity, and then, the effect of salinity on productivity will be observed. When the salinity level influences yield negatively, it is called threshold (TH) point. Furthermore, the variation of crops in tolerating salinity was observed. It is the minimum relative production to be accepted economically by irrigation of saline water reaching $50 \%$ of the maximum production under the same conditions (FAO, 1985).

Many researchers have pointed out that irrigation with different saline water causes direct or indirect harmful effects on plant growth. The direct harmful effect is shown in the inability of the plant to absorb water due to increase osmotic pressure of the soil solution or to cause the imbalance in plant absorption of nutrients and finally reflects on growth and plant yield (Dohuki, 1997 and Sharma et al., 2005). Oscarson (2000) described that wheat (Triticum aestivum L.) as one of the most economically important cultivated plants. Furthermore, it is the dominant crop in temperate countries being used for human food and livestock feed; however, wheat is counted among the 
"big three" cereal crops, with over 600 million tones being harvested annually as described by Shewry (2009).

Both irrigation water quality and proper irrigation management are critical to successful crop production. Lowquality water for irrigation can impose a major environmental constraint to crop productivity and type of amendment on the yield and quality of plants (Al-Omran et al., 2010). In plants, salinity can induce damages in proteins, lipids, and nucleic acids, and alterations in photosynthesis and respiration which affect plant growth and development (Manai et al., 2014 and Hussain et al., 2016).

Growth is suppressed when salinity exceeds beyond a TH value (Tanji, 1990). The higher electrical conductivity (EC) results the less water available to plants, even though a field may appear wet.

The use of saline drainage waters in such environments shows promise for growing agricultural crops (Rhoades, 1987). Salinity is a severe problem which not only reduces the agricultural potential but also creates serious effects on livelihood of farmers (Haider and Hossain, 2013).

Several crops are sensitive to salinity and the negative effect on growth leads to the decrease in yield and quality. For this reason, salinity has been considered as one of the most important factors which affect irrigation water suitability (Beltran, 1999). Irrigating saline water can also result in salt accumulation in soil, leading to the decrease in yield and deterioration in soil resource (Ould et al., 2007, Feizi et al., 2010).

Table 1: The GPS reading for the studied groundwater

\begin{tabular}{llll}
\hline \multirow{2}{*}{ Water quality } & \multicolumn{2}{c}{ Coordinates } & Elevation (m) \\
\cline { 2 - 3 } & Latitude & Longitude & \\
\hline W.q1 & $44^{\circ} 00^{\prime} 28^{\prime \prime}$ & $36^{\circ} 03^{\prime} 06^{\prime \prime}$ & 412.3 \\
W.q2 & $44^{\circ} 00^{\prime} 41^{\prime \prime}$ & $36^{\circ} 06^{\prime} 48^{\prime \prime}$ & 421.6 \\
W.q3 & $43^{\circ} 53^{\prime} 57^{\prime \prime}$ & $35^{\circ} 57^{\prime} 02^{\prime \prime}$ & 338.6 \\
W.q4 & $43^{\circ} 53^{\prime} 22^{\prime \prime}$ & $35^{\circ} 57^{\prime} 48^{\prime \prime}$ & 341.2 \\
W.q5 & $43^{\circ} 36^{\prime} 05^{\prime \prime}$ & $35^{\circ} 46^{\prime} 54^{\prime \prime}$ & 298.4 \\
W.q6 & $43^{\circ} 46^{\prime} 32^{\prime \prime}$ & $35^{\circ} 46^{\prime} 59^{\prime \prime}$ & 300.2 \\
W.q7 & $43^{\circ} 43^{\prime} 09^{\prime \prime}$ & $35^{\circ} 52^{\prime} 23^{\prime \prime}$ & 341.2 \\
\hline
\end{tabular}

Numerous studies were conducted in Kurdistan region about the effect of water quality on soil chemical properties and plant growth by Esmail, 1986, 1992; Dohuki, 1997; Mam Rasul, 2000; Esmail, 2001; Salih, 2008; Baba, 2010; Kareem, 2010; and Alani, 2015.

Most of the mentioned investigations either depended on pot experiment or on corn plant, it means none of them included the effect of saline water under field condition on growth and yield index of wheat, for this reason, the aim of this study was the effect of saline water on yield index of wheat in Erbil plain under field condition.

\section{MATERIALS AND METHODS}

This study was conducted from December 11, 2015, to May 30, 2016, at Grdarasha field, where is located southwest of Erbil about $6 \mathrm{~km}$ from the city center; and the field situated between latitudes of northern $35.253942^{\circ}-36.348443^{\circ}$ and longitudes of eastern $43.264947^{\circ}-44.353321^{\circ}$. The experiment land was equally divided into three plots spaced $75 \mathrm{~cm}$ between the blocks and divided every block to seven experimental units. The dimension of each experimental unit was $150 \mathrm{~cm} \times 75 \mathrm{~cm}$ and the distance between them was $50 \mathrm{~cm}$. Each plot was split to seven experimental units. Seven of EC were used $(0.42,0.50,1.43,2.20,2.60,5.40$, and $5.70 \mathrm{dS} / \mathrm{m}$ ). The randomized complete block design with three replicates was applied.

Wheat seeds (Triticum turgidum L. variety Acsad 65) were planted at a depth of $4 \mathrm{~cm}$ on December 11, 2015, considering $100 \mathrm{~kg} / \mathrm{ha}$. Each experimental unit was seeded with three lines at a distance of $15 \mathrm{~cm}$ from the east to the west. Diammonium phosphate fertilizer was used for all experimental units at a rate of $20 \mathrm{~g}(200 \mathrm{~kg} / \mathrm{ha})$. Collected data of the experiment were plant morphology measurement, cation, and anion in hay and grains protein. The experiment was conducted under natural rainfall conditions; supplemental irrigation was carried out whenever needed (Walker, 1989). Totally, each experimental unit was irrigated by $140.44 \mathrm{~mm}$. The geographical position of the studied wells is presented in Table 1 and their

Table 2: Mean of some chemical properties of irrigation water during the growing season*

\begin{tabular}{|c|c|c|c|c|c|c|c|c|c|c|c|c|c|c|c|}
\hline \multirow{2}{*}{$\begin{array}{l}\text { Water } \\
\text { quality }\end{array}$} & \multicolumn{8}{|c|}{ Concentration $\mathrm{mmol}_{\mathrm{c}} / \mathrm{L}$} & \multirow[t]{2}{*}{$\mathrm{pH}$} & \multirow{2}{*}{$\begin{array}{c}\text { EC dS } \\
m^{-1}\end{array}$} & \multirow[t]{2}{*}{ SAR } & \multirow[t]{2}{*}{$\mathrm{Mg}^{2+} / \mathrm{Ca}^{2+}$} & \multirow[t]{2}{*}{$\mathrm{Mg}^{2+} / \mathrm{Na}^{+}$} & \multirow[t]{2}{*}{ RSC } & \multirow{2}{*}{$\begin{aligned} \mathrm{S} . \mathrm{P}^{* *}= & \left(\mathrm{Cl}^{-}+1 / 2 \mathrm{SO}_{4}{ }^{2-}\right) \\
& \mathrm{mmol}{ }_{\mathrm{c}} / \mathrm{L}\end{aligned}$} \\
\hline & $\mathrm{Ca}^{2+}$ & $\mathrm{Mg}^{2+}$ & $\mathrm{Na}^{+}$ & $\mathbf{K}^{+}$ & $\mathrm{Cl}^{-}$ & $\mathrm{NO}_{3}$ & $\mathrm{SO}_{4}^{2-}$ & $\mathrm{HCO}_{3}^{-}$ & & & & & & & \\
\hline W.q1 & 2.42 & 2.12 & 0.57 & 0.01 & 0.35 & 0.15 & 0.50 & 3.10 & 7.64 & 0.42 & 0.38 & 0.88 & 3.72 & -1.44 & 0.60 \\
\hline W.q2 & 2.64 & 2.07 & 0.42 & 0.01 & 0.30 & 0.15 & 0.82 & 3.15 & 7.63 & 0.50 & 0.27 & 0.78 & 4.93 & -1.56 & 0.71 \\
\hline W.q3 & 4.53 & 4.90 & 2.80 & 0.15 & 1.30 & 0.60 & 4.14 & 5.12 & 7.57 & 1.43 & 1.29 & 1.08 & 1.75 & -4.31 & 3.37 \\
\hline W.q4 & 5.94 & 7.25 & 2.82 & 0.05 & 2.50 & 0.60 & 4.50 & 6.80 & 7.32 & 2.20 & 1.10 & 1.22 & 2.57 & -6.39 & 4.75 \\
\hline W.q5 & 11.55 & 8.65 & 3.22 & 0.15 & 2.82 & 0.08 & 5.35 & 5.40 & 7.22 & 2.60 & 1.01 & 0.75 & 2.69 & -14.80 & 5.50 \\
\hline W.q6 & 17.12 & 14.63 & 9.52 & 0.15 & 8.50 & 0.90 & 25.42 & 5.00 & 7.24 & 5.40 & 2.39 & 0.85 & 1.54 & -26.75 & 21.21 \\
\hline W.q7 & 16.75 & 14.82 & 15.25 & 0.15 & 7.45 & 0.80 & 35.12 & 4.45 & 7.58 & 5.70 & 3.84 & 0.88 & 0.97 & -27.12 & 25.01 \\
\hline
\end{tabular}

* The waters were analyzed 4 times during the field experiment. ${ }^{*}$ S.P: Salinity potential 


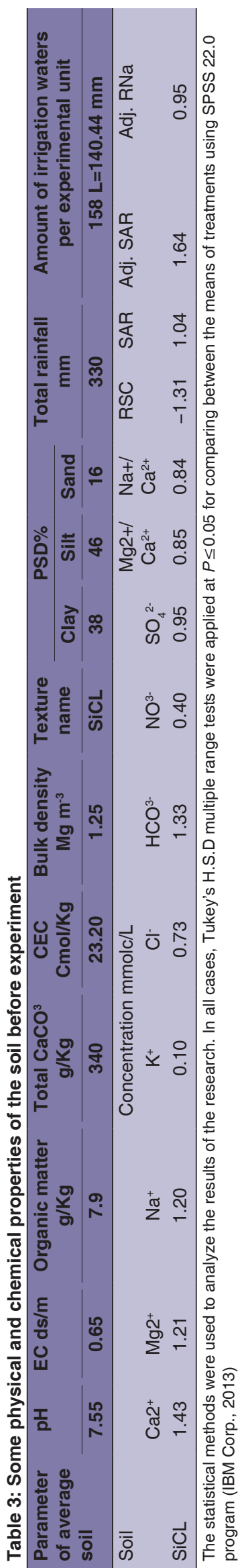

chemical analysis results are given in Table 2. Furthermore, the common physical and chemical parameters of soil were determined as referenced in Table 3 mention the amount of rainfall during the grown season.

\section{RESULTS AND DISCUSSION}

The summary of ANOVA showed that EC of irrigation waters significantly $(P \leq 0.05)$ affected the weight and length of hay and wheat spike [Table 4] (Mohammed and Yassen, 2009) and (Al-Jobouri and AL-Dawdi, 2014). The highest values of hay and spike weight are 96.58 and $139.17 \mathrm{~g}$ and length of hay and spike are 91.08 and $10.57 \mathrm{~cm}$, respectively, recorded from treatment W.q3, while the lowest values 67.49 and $100.01 \mathrm{~g}$ ) and 51.87 and $6.30 \mathrm{~cm}$, respectively, were recorded from treatment W.q5. This was due to the difference in chemical properties of the irrigation water. These results were similar to those recorded by Esmail (1986; 1992), Salih (2008), and Alani (2015). Plant height average at W.q5 was decreased due to inhibition of cell plants elongation and saline stress diminishes amino acid synthesis, as well as some plant hormones that contribute in cell division, which influences negatively plant height (Heron, 2003 and Mohamed et al., 2007).

Table 5 shows the significant effect of water quality $(P \leq 0.05)$ on protein content and weight of 1000 seeds. The increase in water EC caused an increase in protein content and weight of 1000 seeds except treatment W.q5 which recorded the lowest value. This due to the difference in chemical composition of the applied water qualities in irrigation, especially $\mathrm{NO}_{3}{ }^{-}$concentration since the concentration of $\mathrm{NO}_{3}{ }^{-}$in W.q5 is very low $\left(0.08 \mathrm{mmol}_{\mathrm{c}} / \mathrm{L}\right)$ in comparing with other water qualities [Table 2]. These results were similar to those recorded by Esmail (1986; 1992) Salih (2008), and Alani (2015).

The water qualities affected significantly $(P \leq 0.05)$ on concentration of cations in hay [Figure 1], the highest concentration value $7.39,2.22$, and $4.52 \mathrm{mg} / \mathrm{g}$ of $\mathrm{Ca}^{2+}, \mathrm{Mg}^{2+}$, and $\mathrm{Na}^{+}$was recorded from treatment W.q7, respectively, and the highest mean concentration (0.16) of $\mathrm{K}^{+}$was recorded from treatment W.q2, while the minimum concentration $(1.54$ and $1.81 \mathrm{mg} / \mathrm{g})$ of $\mathrm{Ca}^{2+}$ and $\mathrm{Na}^{+}$was obtained from treatment W.q2 and the lowest mean concentration $(0.19 \mathrm{mg} / \mathrm{g})$ of $\mathrm{Mg}^{2+}$ was obtained from treatment W.q3, the minimum concentration $(0.06$ $\mathrm{mmol}_{\mathrm{c}} / \mathrm{L}$ ) of $\mathrm{K}^{+}$was obtained from treatment W.q5. Similar results were obtained by Mostafa et al. (2004). The difference in elements proportions might be due to increasing of $\mathrm{Na}^{+}$, which is absorbed by plant roots faster than $\mathrm{K}^{+}$(Smith, 1966; Julain, 2004; and Mohamed et al., 2007). 
Table 4: Effect of water quality on some growth characters $(\mathrm{g})$ and $(\mathrm{cm})$ of wheat

\begin{tabular}{lcccc}
\hline Water quality & Hay weight $(\mathbf{g})$ & Spike weight $(\mathbf{g})$ & Plant height $(\mathbf{c m})$ & Spike length $(\mathbf{c m})$ \\
\hline W.q1 & 87.25 & 135.13 & 85.47 & 8.87 \\
W.q2 & 89.11 & 113.17 & 85.77 & 8.80 \\
W.q3 & 96.58 & 139.17 & 91.08 & 10.57 \\
W.q4 & 91.39 & 131.16 & 51.77 & 9.27 \\
W.q5 & 67.49 & 100.01 & 83.53 & 6.30 \\
W.q6 & 88.26 & 114.03 & 79.73 & 8.83 \\
W.q7 & 86.07 & 121.32 & 6.67 & 8.00 \\
Tukey's HSD values & 6.68 & 4.70 & 0.62 \\
\hline
\end{tabular}

Table 5: Effect of water quality on concentration of protein percentage in seed and weight of 1000 seeds

\begin{tabular}{lcc} 
Water quality & Protein in seed (\%) & Weight 1000 seed $(\mathrm{g})$ \\
\hline W.q1 & 9.81 & 33.45 \\
W.q2 & 8.52 & 33.44 \\
W.q3 & 12.07 & 33.53 \\
W.q4 & 12.50 & 34.36 \\
W.q5 & 7.26 & 30.02 \\
W.q6 & 13.70 & 34.70 \\
W.q7 & 12.13 & 33.83 \\
Tukey's HSD values & 1.04 & 0.63 \\
\hline
\end{tabular}

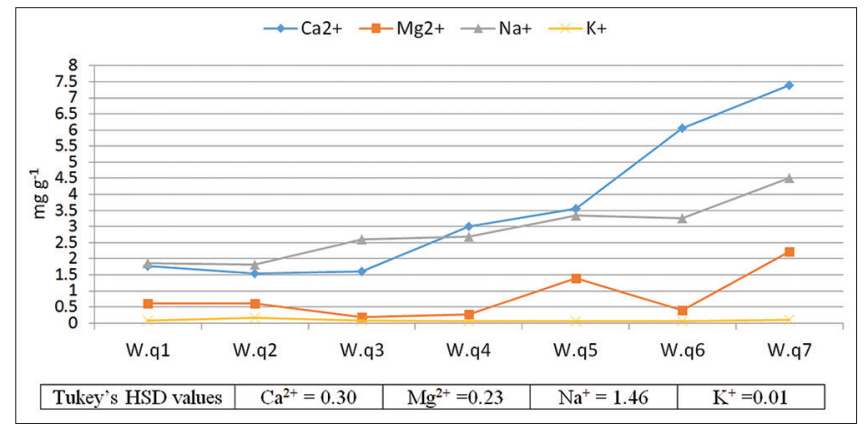

Figure 1: Effect of water quality on cations concentration in hay $(\mathrm{mg} / \mathrm{g})$ after irrigation water

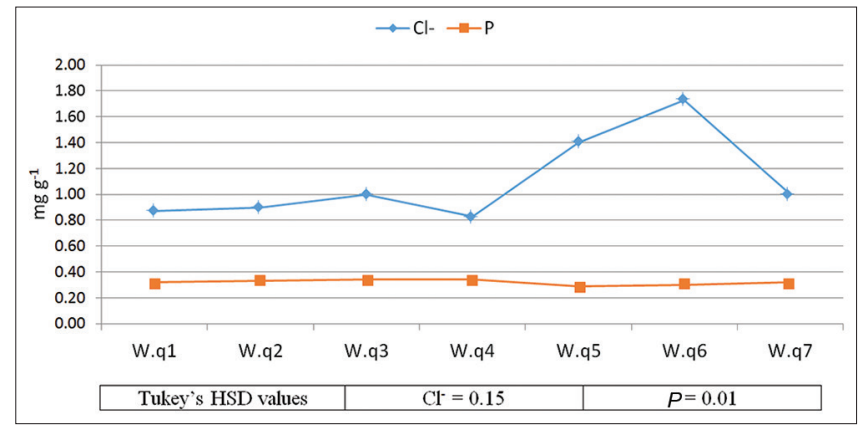

Figure 2: Effect of water quality on chlorine and phosphorus concentration in hay $(\mathrm{mg} / \mathrm{g})$ after irrigation water

In Figure 2, the statistical analysis shows the significant difference between concentration of $\mathrm{Cl}^{-}$and $\mathrm{P}$ in hay wheat. The highest concentration $(1.73 \mathrm{mg} / \mathrm{g})$ of $\mathrm{Cl}^{-}$was recorded from treatment W.q6, the highest concentration $(0.34 \mathrm{mg} / \mathrm{g})$ of P was recorded from treatment W.q3. On the other hand, the lowest concentration $(0.83 \mathrm{mg} / \mathrm{g})$ of $\mathrm{Cl}^{-}$was recorded from treatment W.q4 and the lowest concentration $(0.29 \mathrm{mg} / \mathrm{g})$ of $\mathrm{P}$ was recorded from treatment W.q5. This may be due to chemical composition of irrigation water, especially $\mathrm{Mg}^{2+} / \mathrm{Ca}^{2+}$ ratio [Table 2]. These results agree with those recorded by Esmail (1986), Al-Azawi (1986), and Esmail et al. (2000), Salih (2008), Alani (2015), and Esmail and Rajab (2018). Low significant variations were due to the ability of wheat plant to tolerate such levels of saline stress and the leaching of $\mathrm{Cl}^{-}$by rain (Al-Azawi, 1986; Yasseen et al., 1989; and Salih, 2008).

\section{RECOMMENDATIONS}

Groundwater of the study area is main source of irrigation to field crops. Hence, it is required to conduct more experiments in future on different field crops, particularly wells that suffer more from saline stress to choose best tolerant crop to cultivate in such areas. It is also recommended that these regions can be monitored or supervised by experts of the ministry of agriculture continuously to avoid the risk of saline stress.

\section{REFERENCES}

Alani, A. S. K. 2015. The Chemical Composition of Irrigation Water and it is Effect on Ion Pairing, Some Chemical Properties of Soil and Plant Growth, Erbil-Kurdistan Region-Iraq. M.Sc. Thesis. College of Agricultural University of Salahaddin, Iraq.

Al-Azawi, S. S. H. 1986. Effect of Irrigation by Ground Water from Erbil Plain on Soil and Wheat Plant. MSc. Thesis. College of Agriculture. Salahaddin University Iraq, In Arabic, Iraq.

Al-Jobouri, K. K. A. and A. H. R. Al-Dawdi. 2014. Response of bread wheat varieties (Triticum aestivum L.) to irrigated water quality. Tikrit J. Agric. Sci. 14(2): 85-95.

Al-Omran, A. M., A. R. Al-Harbi, M. A. Wahba-allah, M. Nadeem and A. Aleter. 2010. Impact of irrigation water quality, irrigation systems, irrigation rates and soil amendments on tomato production in sandy calcareous soil. Turk. J. Agric. For. 34(1): 59-73.

Baba, A. B. A. 2010. The Role of Chemical Composition of Some Water Resources in Limiting its Suitability for Irrigation Purpose in Sulaimani Governorate Kurdistan Region. MSc. Thesis. College of Agricultural University. of Salahaddin. Iraq.

Beltran, J. M. 1999. Irrigation with saline water: Benefits and environmental impact. Agric. Water Manage. 40: 183-194. 
Dohuki, M. S. S. M. 1997. Evaluation of Some Wells and Springs Water in Dohuk Governorate for Irrigation and Drinking Purpose. M.Sc. Thesis. College of Science University of Salahadin Iraq, in Arabic, Iraq.

Dohuki, M. S. S., M. A. J. Al-Obaidi and A. O. Esmail. 2013. Effect of water quality on growth and yield of (Zea mays $L$.) in calcareous soil from Erbil provenance in Kurdistan region-Iraq. J. Kirkuk Univ. Agric. Sci. 4(2): 1-9.

Esmail, A. O. 1986. Limitation of Some Ground Water Suitability in Erbil Plain for Different Uses. MSc. Thesis. College of Agriculture Salahaddin Univerdity, Iraq.

Esmail, A. O. 1992. Effect of Composition and Ion Pair in Irrigation Water on Soil and Plant. Ph. D. Thesis, College of Agriculture. Baghdad University, Iraq.

Esmail, A. O. 2001. Role of ionic activity in relation between ionic strength and electrical conductivity of ground water in Arbil plain. J. Dohuk Univ. 4(2): 73-77.

Esmail, A. O. and K. S. Rajab. 2018. Effect of chemical composition of irrigation water on some growth and yield of corn and P-availability in calcareous soil. J. Zankoy Sulaimani. 20(10): 1-20.

Esmail, A. O., K. H. M. Kawa and M. F. Yadgar. 2000. Effect of $\mathrm{Mg}^{2+}$ $\mathrm{Ca}^{2+}$ ratio of irrigation water on the yield and quality of chickpea. Salahaddin Univ. J. Zanco. 11(2): 1-8.

Esmail, A. O., P. M. Maulood and Y. A. Shekha. 2007. Evaluate Kasnazan Impoundment Water for Irrigation Purposes. J. Educ. Sci. 20(2): 47-56.

FAO. 1985. Water Quality for Agriculture. Irrigation and Drainage Paper, Rome Italy. p174.

Feizi, M., M. A. Hajabbasi and B. Mostafazadeh-fard. 2010. Saline irrigation water management strategies for better yield of safflower (Carthamus tinctorius L.) in an arid region. Aust. J. Crop Sci. 4: 408-414.

Haider, Z. M. and Z. M. Hossain. 2013. Impact of salinity on livelihood strategies of farmers. J. Soil Sci. Plant Nutr. 13: 417-431.

Heron, C. 2003. Tolerance of citrus rootstock seedlings to saline stress based on their ability to regulate ion uptake and transport. Tree Physiol. 23(4): 265-271.

Hussain, Z., R. A. Khattak, M. Irshad, Q. Mahmood and P. An. 2016. Effect of saline irrigation water on the leachability of salts, growth and chemical composition of wheat (Triticum aestivum L.) in saline-sodic soil supplemented with phosphorus and potassium. J. Soil Sci. Plant Nutr. 16(3): 604-620.

IBM Corp Released. 2013. IBM SPSS Statistics for Windows, Version 22.0. IBM Corp, Armonk, NY.

Julain, W. 2004. Text Citrus Subtropical Fruits Nutrition and Fertilization. Horticulture Tax as Cooperative Extension.

Kareem, A. S. 2010. Effect of Water Quality and Soil Texture on Some Chemical Properties of Soil and Growth of Corn (Zea Mays L.). High Diploma. College of Agriculture University of Salahaddin, Iraq.

Mam Rasul, G. A. 2000. Effect of Ionic Activity on Classification of Irrigation Water and Availability of Some Nutrients in Sulaimani City. MSc. Thesis. College of Agriculture Sulaimani University, Iraq.

Manai, J., T. Kalai, H. Gouia and F. J. Corpas. 2014. Exogenous nitric oxide (NO) ameliorates salinity-induced oxidative stress in tomato (Solanum lycopersicum) plants. J. Soil Sci. Plant Nutr. 14: 433-446.

Mohamed, K. H. O., A. H. Abdulwahid and A. N. Obeid. 2007. The effect of irrigation water salinity on growth and concentration of NPK in sour orange (Citrus aurantium L). Seedling. J. Basrah Iraq 20(1): 27-35.

Mohammed, Z. M. and A. Yassen. 2009. Effect of four different water sources on growth and yield for two bread wheat varieties (Triticum aestivum L.) Kirkuk Univ. J. Sci. Stud. 4(1): 58-71.

Mostafa, M. A., M. O. Elsharawy and F. M. Elboraei. 2004. Use of Sea Water for Wheat Irrigation II. Effect on Soil Chemistry Properties, Actual Evapotranspiration and Water use Efficiency. International Conference, On Water Resources and Arid Environment.

Oscarson, P. 2000. The strategy of the wheat in acclimating growth and grain production to nitrogen availability. J. Exp. Bot. 51(352): 1921-1929.

Ould, A. B. A., T. Yamamoto and M. Inoue. 2007. Response of drip irrigated sorghum varieties growing in dune sand to salinity levels in irrigation water. J. Appl. Sci. 7: 1061-1066.

Persons and Ralph Engineering Company. 1955. Ground Water Resource of Iraq. Hydrology Aspects of Selected Areas. Vol. 4. Development Board, Ministry of Development Governorate. Baghdad, Iraq.

Rajab, K. S. 2015. Classification of Some Groundwater for Irrigation Purpose Depending on IWQI in Erbil Plain Iraqi Kurdistan Region. M.Sc. Thesis. Soil and Water Sciences-College of Agri Salahaddin University, Iraq.

Rhoades, J. D. 1987. Use of saline water irrigation. Water Qual. Bull. 12: 14-22.

Salih, H. O. 2008. The Role of Ionic Activity in Classification of Some Groundwater on Soil Chemical Properties and Wheat Yield in Erbil Plain. M.Sc. Thesis. College of Agriculture University of Salahaddin, Iraq.

Salih, H. O. 2018. Effect of ion pairs and ion activity on calculation of groundwater salinity-potential in different soil depths. Erbil Polytech. J. 8(2): 44-59.

Sharma, D., D. Singh and P. S. Kumbbare. 2005. Response of sunflower to conjunctive use of saline drainage water and nonsaline canal water irrigation. Arch. Agron. Soil Sci. 1: 91-100.

Shewry, P. R. 2009. Darwin review wheat. J. Exp. Bot. 60(6): 1537-1553.

Smith, F. P. 1966. Citrus Nutrition. In: Childers, N. editor. Fruit Nutrition. Horticultural Publications, Rutgers University, New Jersey.

Tanji, K. K. 1990. Agricultural Salinity Assessment and Management. American Society of Civil Engineers, Reston. p615.

Walker, W. R. 1989. Guidelines for Designing and Evaluating Surface Irrigation Systems. Irrigation and Drainage Paper No. 45, Food and Agriculture Organization, Rome, Italy.

Yasseen, B. T., J. A. Juries., S. A. Sofajy and J. A. Said. 1989. Effect of $\mathrm{NaCl}$ on leaf growth and ionic composition of two barley cultivaes. Mesopotamia J. Agric. 21(1): 19-32. 